\title{
Metabolism of a New 1,4-dihydropyridine Calcium Antagonist, Pranidipine, by cDNA-expressed Human Cytochrome P450
}

\author{
Shoji Kudo, Hiroshi OKumura, Masaaki Odomi and Gohachiro MiYamoto \\ Tokushima Research Institute, Otsuka Pharmaceutical Co., Ltd., \\ 463-10 Kagasuno Kawauchi-cho, Tokushima 771-0192, Japan
}

\begin{abstract}
Summary: To determine human cytochrome P450 isoform(s) (CYPs) involved in the metabolism of pranidipine, a new potent and long-acting 1,4-dihydropyridine calcium antagonist, the biotransformation of the compound was investigated in vitro using ten isoforms of human cytochrome P450 expressed in human AHH-1 TK $+/-$ cell lines. Modulation of an ethyl acetate-extract of grapefruit juice on the activity of CYP3A4-mediated pranidipine metabolism was also investigated.

1. Pranidipine was dehydrogenated into pyridine metabolite by CYP3A4 with $\mathrm{Km}$ and $\mathrm{V}_{\max }$ values of $21.4 \mu \mathrm{M}$ and $0.110 \mathrm{nmol} / \mathrm{min} / \mathrm{mg}$ protein, respectively. CYP1A1, 1A2, 2A6, 2B6, 2C8, 2C9, 2C19, 2D6 and $2 \mathrm{E} 1$ were not involved in the pranidipine metabolism.

2. MOP-13031 constructed with dihydropyridine ring, a metabolite of pranidipine, was also oxidized into pyridine ring by the multi-isoforms of cytochrome P450 including CYP3A4, 2C19, 2D6 and 2E1. The $\mathrm{Km}$ and $\mathrm{V}_{\max }$ values on the oxidation of MOP-13031 to pyridine metabolite by CYP3A4 were $796 \mu \mathrm{M}$ and $0.124 \mathrm{nmol} / \mathrm{min} / \mathrm{mg}$ protein, respectively.

3. CYP3A4-mediated testosterone $6 \beta$-hydroxylase activity was competitively inhibited by pranidipine with a Ki value of $5.44 \mu \mathrm{M}$ but was not affected by MOP-13031 up to a concentration of $100 \mu \mathrm{M}$. ( \pm ) Miconazole inhibited the hydroxylation up to $94.7 \%$ at $10 \mu \mathrm{M}$.

4. CYP3A4-mediated pranidipine dehydrogenase activity was dose-dependently decreased by an addition of the ethyl acetate-extract of grapefruit juice.
\end{abstract}

Key words: Pranidipine, CYP3A4, Dehydrogenation, Grapefruit juice, cDNA-expressed microsomes

\section{Introduction}

Pranidipine, ( \pm )-methyl 3-phenyl-2(E)-propenyl 1,4-dihydro-2,6-dimethyl-4-(3-nitrophenyl)-3,5-pyridinedicarboxylate, is a new potent and long-acting 1,4dihydropyridine calcium antagonist ${ }^{1-4)}$ that is being developed as a therapeutic drug for the treatment of essential hypertension and angina pectoris. ${ }^{5-9)}$

The absorption, distribution and excretion of pranidipine were previously reported in rats and dogs following oral or intravenous administration. ${ }^{10-12)}$ The absolute bioavailability of pranidipine following oral dosing at 1 $\mathrm{mg} / \mathrm{kg}$ was $4.8 \%$ in rats and $6.8 \%$ in dogs, ${ }^{10)}$ and the AUC of unchanged pranidipine accounted for $6.3 \%$ of that of total radioactivity in plasma in dogs receiving oral dose of radiolabeled pranidipine at $\left.10 \mathrm{mg} / \mathrm{kg},{ }^{11}\right)$ showing extensive metabolism of the compound in the animals.

Several metabolic pathways of pranidipine have been identified in animals and humans, indicating the dehydrogenation of 1,4-dihydropyridine to pyridine ring, hydrolysis of the carbonylester, hydroxylation of the methyl group and glucuronide conjugation (Fig. 1) ${ }^{13,14)}$ In humans, it has been considered that the elimination of pranidipine from the circulation was based on the metabolic clearance since no urinary excretion of unchanged pranidipine was observed in healthy subjects received an oral dose of the drug. ${ }^{14)}$ OPC -13463 , which is a metabolite of pranidipine produced by the dehydrogenation of 1,4-dihydropyridine to pyridine ring and the hydrolysis of the carbonylester at the 3-position of pranidipine, is one of the main metabolites of pranidipine. ${ }^{13)}$

Identification of the human cytochrome P450(s) responsible for the metabolism of a drug is necessary for predicting any potential drug interaction or food interaction, particularly grapefruit juice, in therapeutic use. In this study, we examined the metabolism of pranidipine using ten human cDNA-expressed cytochrome $\mathrm{P} 450$ forms and identified CYP isoform responsible for the metabolism. We further demonstrated the modulating effect of an ethyl acetate-extract of grapefruit juice on the activities of CYP3A4-mediated pranidipine metabolism.

\section{Materials and Methods}

\section{Chemicals and Reagents}

Pranidipine, methyl 3-phenyl-2(E)-propenyl 2,6dimethyl-4-(3-nitrophenyl)-3,5-pyridinedicarboxylate

大塚製薬株式会社 徳島研究所 $\overline{\mathbf{T}} 771-0192$ 徳島市川内町加賀須野 463-10 
<smiles>CCOC(=O)C1=C(C)NC(C)=C(C(=O)OCC=Cc2ccc(CC)cc2)C1c1cccc([N+](=O)[O-])c1</smiles>

OPC-13703<smiles>CC(=O)OC(=O)C1=C(C)NC(C)=C(C(=O)OCC=Cc2ccccc2)C1c1cccc([N+](=O)[O-])c1</smiles><smiles>CC(=O)OC(=O)C1(C(=O)O)C(C)=C(C)NC(C)=C1C(=O)O</smiles>

MOP-13031<smiles></smiles>

OPC-13448

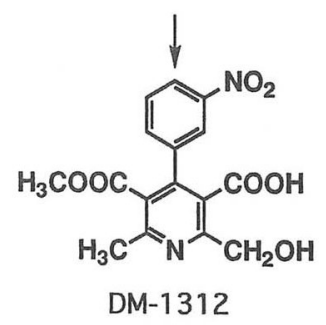

Fig. 1 Presumed metabolic pathways of pranidipine

(OPC-13448), methyl 2,6-dimethyl-4-(3-nitrophenyl) -3-carboxy-5-pyridinecarboxylate (OPC-13463), ( \pm ) -methyl 1,4-dihydro-2,6-dimethyl-4-(3-nitrophenyl)3-carboxy-5-pyridine carboxylate (MOP-13031) and methyl 2-hydroxy-4-(3-nitrophenyl)-6-methyl-3-carboxy -5 -pyridinecarboxylate (DM-1312) were provided by Otsuka Pharmaceutical Co., Ltd. (Tokyo, Japan). Testosterone, $6 \beta$-hydroxytestosterone, $( \pm)$-miconazole, $\beta$-NADPH tetrasodium salt and $\beta-\mathrm{NADH}$ disodium salt were purchased from Sigma Chemical Co. (St. Louis, MO. USA). All other reagents and solvents were of high analytical grade.

\section{Human cDNA-expressed Cytochrome P450s}

Microsomes derived from human AHH-1 TK +/cells expressed human cytochrome P450s were purchased from Gentest Corp. (Woburn, MA. USA). The following microsome expressed cytochrome P450s were used in this study: microsome expressed CYP1A1 (34 pmol $\mathrm{P} 450 / \mathrm{mg}$ protein, 7-ethoxyresorufin deethylase activity: $420 \mathrm{pmol} / \mathrm{min} / \mathrm{mg}$ protein, lot 15$)$, CYP1A2 (117 pmol/mg, 7-ethoxyresorufin deethylase activity: $170 \mathrm{pmol} / \mathrm{min} / \mathrm{mg}$ protein, lot 37), CYP2A6 and P450 reductase $(83 \mathrm{pmol} / \mathrm{mg}$, coumarin 7-hydroxylase: 2430 $\mathrm{pmol} / \mathrm{min} / \mathrm{mg}$, lot 24), CYP2B6 (120 pmol/mg, 7ethixy-4-trifluoromethyl-coumarin deethylase: 220 $\mathrm{pmol} / \mathrm{min} / \mathrm{mg}$, lot 33), CYP2C8 (40 pmol/mg, 5 (and 6) -chloromethylfluorescein diethyl ether deethylase: 1 $\mathrm{pmol} / \mathrm{min} / \mathrm{mg}$, lot 10), CYP2C9-cys and $\mathrm{P} 450$ reduc- tase $(37 \mathrm{pmol} / \mathrm{mg}$, diclofenac 4'-hydroxylase: 226 $\mathrm{pmol} / \mathrm{min} / \mathrm{mg}$, lot 22$),$ CYP2C19 (16 pmol/mg, (s)mephenytoin $4^{\prime}$-hydroxylase: $21 \mathrm{pmol} / \mathrm{min} / \mathrm{mg}$, lot 4$)$, CYP2D6-val and P450 reductase (44 pmol $/ \mathrm{mg},(+)-$ bufuralol 1'-hydroxylase: $870 \mathrm{pmol} / \mathrm{min} / \mathrm{mg}$, lot 9 ), CYP2E1 and P450 reductase $(150 \mathrm{pmol} / \mathrm{mg}, \mathrm{p}-$ nitrophenol hydroxylase: $1430 \mathrm{pmol} / \mathrm{min} / \mathrm{mg}$, lot 25), and CYP3A4 and P450 reductase $(56-65 \mathrm{pmol} / \mathrm{mg}$, testosterone $6 \beta$-hydroxylase: $1000-2380 \mathrm{pmol} / \mathrm{min} / \mathrm{mg}$, lot $9,15,19,25$ and 42$)$. The values listed were provided by the manufacturer.

\section{Grapefruit Juice Extract}

Grapefruit juice was all commercially available. Two reconstituted frozen concentrated (products of Florida, USA, by Tropicana and Dole Food Company Inc.) and one fresh regular-strength (Dole ${ }^{\circledR}$ straight select $100 \%$, Indian River, Florida, USA) grapefruit juice was used in this study.

$2 \mathrm{~m} l$ grapefruit juice was combined with $5 \mathrm{~m} l$ ethyl acetate and shaken for $10 \mathrm{~min}$. After centrifuging at $3000 \mathrm{rpm}$ for $10 \mathrm{~min}, 4 \mathrm{~m} l$ of the organic phase was evaporated to dryness under a stream of nitrogen. The samples extracted were dissolved in $50 \mu \mathrm{l}$ of methanol to prepare a stock solution for grapefruit juice extracts. The solution was diluted with methanol to obtain an adequate concentration of the extracts and used in subsequent experiments. 
4. Assay Procedure for Pranidipine=, MOP13031- or OPC-13463-metabolizing Activity

In the experiment to identify the CYP isoform(s) involved in the metabolism of pranidipine, MOP-13031 and $\mathrm{OPC}-13463$, a $0.5 \mathrm{~m} l$ reaction mixture containing 2 $\mathrm{mg} / \mathrm{m} l$ microsomal protein, $5 \mathrm{mM} \beta-\mathrm{NADPH}, 2.5 \mathrm{mM}$ $\beta-\mathrm{NADH}$, and $100 \mu \mathrm{M}$ pranidipine, MOP-13031 or OPC-13463 was incubated for $2 \mathrm{hr}$ at $37^{\circ} \mathrm{C} .100 \mathrm{mM}$ Tris- $\mathrm{HCl}$ buffer, $\mathrm{pH}$ 7.4, was used for the CYP2A6 and 2C9 incubation mixtures, and $100 \mathrm{mM}$ phosphate buffer, $\mathrm{pH}$ 7.4, was used for all other CYP reaction mixtures. The substrates were all dissolved with $\mathrm{N}, \mathrm{N}$-dimethylformamide (DMF) and added to the reaction mixtures. The final concentration of DMF was $1 \%(\mathrm{v} / \mathrm{v})$ in the reaction mixture.

The rate of formation of the dehydrogenated pranidipine (OPC-13448) was determined over the pranidipine concentration range of $50-200 \mu \mathrm{M}$ in a reaction mixture containing $0.4 \mathrm{mg} / \mathrm{ml}$ of microsomal protein expressing CYP3A4. A $0.5 \mathrm{~m} l$ reaction mixture, including cofactors, was incubated for $15 \mathrm{~min}$ at $37^{\circ} \mathrm{C}$ in an atmosphere of air. The reaction rate was linear with incubation time under this condition. The rate of formation of OPC13463 was determined over the MOP-13031 concentration range of $100-500 \mu \mathrm{M}$ in a reaction mixture containing $0.5 \mathrm{mg} / \mathrm{ml}$ of microsomal protein expressing CYP3A4. Incubation was performed for $30 \mathrm{~min}$ since the reaction rate was linear up to the incubation time.

Reactions were quenched by adding $0.5 \mathrm{~m} l$ methanol. Reaction-terminated samples were centrifuged at $12,000 \mathrm{rpm}$ for $10 \mathrm{~min}$, and $50 \mu \mathrm{M}$ of the supernatant was analyzed by HPLC.

\section{Effect of Grapefruit Juice-extract on CYP3A4- mediated Pranidipine Dehydrogenation}

A reaction mixture $(0.48 \mathrm{ml})$ containing $10 \mu \mathrm{M}$ pranidipine, $5 \mathrm{mM} \beta-\mathrm{NADPH}$ and $2.5 \mathrm{mM} \beta-\mathrm{NADH}$ was preincubated for $3 \mathrm{~min}$ in $100 \mathrm{mM}$ phosphate buffer, $\mathrm{pH} 7.4$, and then, the reaction was initiated by the addition of $20 \mu l$ CYP3A4-expressing microsomal suspension ( $10 \mathrm{mg}$ protein $/ \mathrm{ml}, 56 \mathrm{pmol} \mathrm{P} 450 / \mathrm{mg}$ protein). Incubation was performed in an atmosphere of air for $20 \mathrm{~min}$. An ethyl acetate-extract of grapefruit juice was added to the reaction mixture before initiation of the reaction at final concentrations of $0.002-0.32$ equivalence to original volume of grapefruit juice. ${ }^{15)}$ The final concentration of methanol used as a solvent for the extract was $1 \%(\mathrm{v} / \mathrm{v})$ in the mixture.

Samples after incubation were combined with $5 \mathrm{ml}$ ethyl acetate and shaken for $10 \mathrm{~min}$. After centrifuging at $3000 \mathrm{rpm}$ for $10 \mathrm{~min}, 4 \mathrm{ml}$ of the organic phase was evaporated to dryness under a stream of nitrogen. The samples extracted were dissolved in $100 \mu l$ of methanol, and $30 \mu l$ of the solution was analyzed by HPLC.
6. Effect of Pranidipine and MOP-13031 on CYP3A4-mediated Testosterone 6 $\beta$-hydroxylation

Testosterone $6 \beta$-hydroxylation was assayed in microsomes expressing human cytochrome P450 as index of CYP3A4 activity. The effects of pranidipine, MOP13031 and of the inhibitor probe, $( \pm)$-miconazole, for the isoform were examined.

Incubation system for the assay of testosterone $6 \beta$ hydroxylation contained $120 \mu \mathrm{M}$ testosterone, $0.25 \mathrm{mg}$ microsomal protein, $5 \mathrm{mM} \beta-\mathrm{NADPH}, 2.5 \mathrm{mM} \beta-$ $\mathrm{NADH}$ and $100 \mathrm{mM}$ phosphate buffer, $\mathrm{pH} 7.4$, in a final colume of $0.5 \mathrm{ml}$. Pranidipine, MOP-13031 or $( \pm)-$ miconazole was added to the above reaction mixture at concentrations of $1 \times 10^{-6}-1 \times 10^{-4} \mathrm{M}, 1 \times 10^{-6}-1 \times$ $10^{-4} \mathrm{M}$ and $1 \times 10^{-7}-1 \times 10^{-5} \mathrm{M}$, respectively. The reaction mixture was incubated for $30 \mathrm{~min}$ at $37^{\circ} \mathrm{C}$ and the reaction was terminated by adding $0.5 \mathrm{~m} l$ methanol. $50 \mu l$ supernatant fraction of the terminated sample obtained by centrifuging at $12,000 \mathrm{rpm}$ was analyzed by HPLC to determine $6 \beta$-hydroxytestosterone.

To estimate the apparent $\mathrm{Ki}$ value for pranidipine regarding the reaction, the rate of testosterone $6 \beta$-hydroxylation was determined as described above in incubation systems containing final concentrations of $50-200 \mu \mathrm{M}$ for testosterone and $0-30 \mu \mathrm{M}$ for pranidipine.

\section{HPLC Analysis}

The HPLC apparatus included two Model 510 HPLC pumps (Waters), a Model WISP 712 auto sample processor (Waters), a Model 680 solvent programmer (Waters), a Model 484 or 486 tunable absorbance detector (Waters), and a Chromatopac C-R3A, C-R6A and C-R7A (Shimadzu). TSK gel ODS-80 Ts column (4.6 $\mathrm{mm}$ internal diameter $\times 150 \mathrm{~mm}$; Tosoh) equipped with a TSK guardgel ODS-80 $\mathrm{TS}$ guard column $(3.2 \mathrm{~mm}$ i.d. $\times 15 \mathrm{~mm}$; Tosoh) was used for the analysis.

The mobile phase used for pranidipine, MOP-13031 or OPC-13463 metabolism was a solution of $5 \% \mathrm{CH}_{3} \mathrm{CN}$ in water containing $1 \%$ acetic acid as solution $\mathrm{A}$ and $\mathrm{a}$ solution of $80 \% \mathrm{CH}_{3} \mathrm{CN}$ in water containing $1 \%$ acetic acid as solution $\mathrm{B}$, and a linear gradient from $10 \%$ to $80 \%$ solution B in 60 min following isocratic elution with $80 \%$ solution $\mathrm{B}$ in $10 \mathrm{~min}$ in a mixture of solution $\mathrm{A}$ and $\mathrm{B}$ was used for the determination of OPC-13448, MOP13031, OPC-13463 and DM-1312. The flow rate was $1.0 \mathrm{ml} / \mathrm{min}$, and UV detection was performed at 254 $\mathrm{nm}$. The retention times for OPC-13463, DM-1312 m MOP-13031, pranidipine, and OPC-13448 were 15.5, $17.8,32.5,60.3$, and $62.5 \mathrm{~min}$, respectively.

The mobile phase used for the determination of OPC13448 in the study for the modulation of grapefruit juiceextract on the pranidipine metabolism was a solution of $10 \% \mathrm{CH}_{3} \mathrm{CN}$ in water containing $0.2 \%$ trifluoroacetic acid as solution $\mathrm{A}$ and a solution of $90 \% \mathrm{CH}_{3} \mathrm{CN}$ in water containing $0.2 \%$ trifluoroacetic acid as solution $\mathrm{B}$, and a linear gradient from $50 \%$ to $80 \%$ solution $\mathrm{B}$ in a mixture 
of solution A and B in 30 min was performed. The flow rate and UV detection were same as described previously. The retention times for OPC -13448 and pranidipine were 17 and $21 \mathrm{~min}$, respectively.

The mobile phase used for testosterone metabolism was similar to that for pranidipine, MOP-13031 or OPC-13463 metabolism. The flow rate and UV detection were $1.0 \mathrm{ml} / \mathrm{min}$ and $254 \mathrm{~nm}$, respectively. The retention times for $6 \beta$-hydroxytestosterone and testosterone were about 25 and $36 \mathrm{~min}$, respectively.

Calibration curves for OPC-13448, OPC-13463, DM1312, MOP-13031 and $6 \beta$-hydroxytestosterone were established by an absolute standard method with the respective standard solution at $2 \mu \mathrm{g} / \mathrm{ml}$ (100 ng per assay). Detection limit for OPC-13448, OPC-13463, DM1312 and MOP-13031 were all $1 \mathrm{ng}$ per injection in the HPLC assay. OPC-13448 was also determined using an absolute standard method with a calibration range of $0.006-6 \mu \mathrm{g} / \mathrm{m} l(\gamma=0.999)$.

\section{Calculations}

Michaelis-Menten parameters were calculated from the linear regression line obtained by a LineweaverBurk reciprocal plot. The Ki value was calculated from the linear regression line obtained by a Dixon plot.

\section{Results}

1. Metabolism of Pranidipine, MOP-13031 and OPC-13463 by Various CYP Isoforms

The catalytic properties of each human CYP isoform for the metabolism of pranidipine are shown in Table I. The results showed that only CYP3A4 was involved in the metabolism of pranidipine. Dehydrogenated pyridine metabolite of pranidipine, OPC-13448, was produced by the enzyme catalysis, and the production activity was $70.9 \mathrm{nmol} / 2 \mathrm{hr} / \mathrm{nmol}$ P450. MOP-13031, OPC13463 and DM-1312 were not produced by any of the CYP isoforms. Kinetic plots for pranidipine de- hydrogenase activity catalyzed by CYP3A4 verus the concentration of pranidipine are shown in Fig. 2. The apparent $\mathrm{Km}$ and $\mathrm{V}_{\max }$ values, determined by Lineweaver-Burk representation, were $21.4 \mu \mathrm{M}$ and $0.110 \mathrm{nmol} / \mathrm{min} / \mathrm{mg}$ protein, respectively.

The catalytic properties of each CYP isoform on the metabolism of MOP-13031 are shown in Table II. The results showed that CYP2C19, 2D6, 2E1 and 3A4 were involved in the metabolism of MOP-13031 and these isoforms produced dehydrogenated MOP-13031, OPC13463. The production activity was $11.2,3.18,0.633$ and $18.8 \mathrm{nmol} / 2 \mathrm{hr} / \mathrm{nmol} \mathrm{P} 450$, respectively, showing

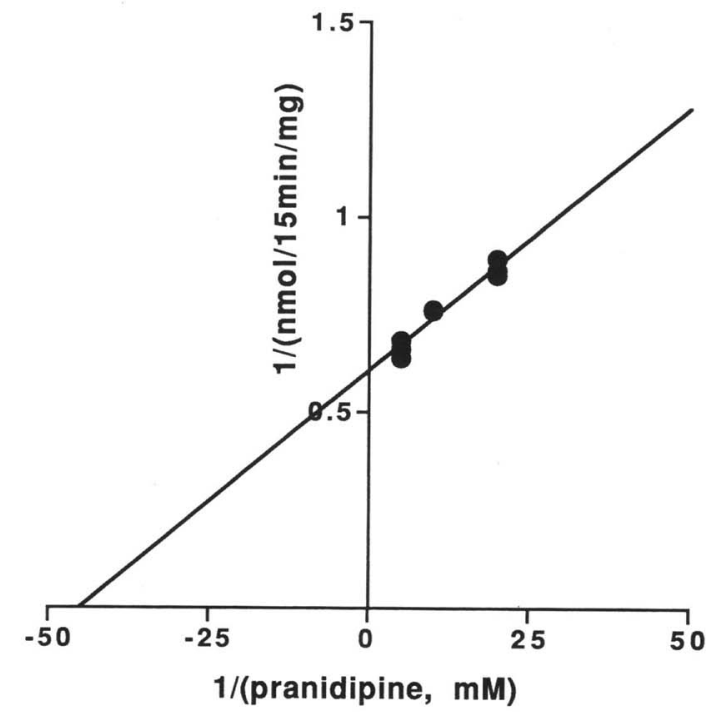

Fig. 2 Lineweaver-Burk plot of the initial velocity of pranidipine dehydrogenation by microsome-expressed CYP3A4.

Enzyme incubation and metabolite analysis were carried out three times. The linear regression line was $y=0.013 x+0.607 \quad(y=0.971), \quad$ yielding estimates $21.4 \mu \mathrm{M}$ for the $\mathrm{Km}$ value and $0.110 \mathrm{nmol} / \mathrm{min} / \mathrm{mg}$ protein for the $\mathrm{V}_{\max }$ value.

Table I Catalytic properties of human cDNA-expressed cytochrome P 450 on pranidipine metabolism

\begin{tabular}{|c|c|c|c|c|}
\hline \multirow{2}{*}{ CYP* } & \multicolumn{4}{|c|}{ Formation rate $(\mathrm{nmol} / 2 \mathrm{hr} / \mathrm{nmol} \mathrm{P} 450)$} \\
\hline & OPC-13448 & MOP-13031 & OPC-13463 & DM-1312 \\
\hline CYP1A1 & $<2.71$ & $<1.37$ & $<2.41$ & $<4.71$ \\
\hline CYP1A2 & $<0.786$ & $<0.398$ & $<0.701$ & $<1.37$ \\
\hline CYP2A6 & $<1.11$ & $<0.561$ & $<0.988$ & $<1.93$ \\
\hline CYP2B6 & $<0.767$ & $<0.388$ & $<0.683$ & $<1.33$ \\
\hline CYP2C8 & $<2.30$ & $<1.17$ & $<2.05$ & $<4.00$ \\
\hline CYP2C9 & $<2.49$ & $<1.26$ & $<2.22$ & $<4.32$ \\
\hline CYP2C19 & $<5.75$ & $<2.91$ & $<5.13$ & $<10.0$ \\
\hline CYP2D6 & $<2.09$ & $<1.06$ & $<1.86$ & $<3.64$ \\
\hline CYP2E1 & $<0.613$ & $<0.311$ & $<0.547$ & $<1.07$ \\
\hline CYP3A4 & 70.9 & $<0.717$ & $<1.26$ & $<2.46$ \\
\hline
\end{tabular}

* Human AHH-1 TK +/ - cell microsomes expressing human cytochrome P 450.

Enzyme incubation and metabolite analysis were carried out in duplicate.

Inequality indicates below the detection limit. 
Table II Catalytic properties of human cDA-expressed cytochrome $\mathrm{P} 450$ on MOP-13031 metabolism

\begin{tabular}{ccc}
\hline \multirow{2}{*}{ CYP* } & \multicolumn{2}{c}{ Formation rate $(\mathrm{nmol} / 2 \mathrm{hr} / \mathrm{nmol} \mathrm{P} 450)$} \\
\cline { 2 - 3 } & OPC -13463 & $\mathrm{DM}-1312$ \\
\hline CYP1A1 & $<2.41$ & $<4.71$ \\
CYP1A2 & $<0.701$ & $<1.37$ \\
CYP2A6 & $<0.988$ & $<1.93$ \\
CYP2B6 & $<0.683$ & $<1.33$ \\
CYP2C8 & $<2.05$ & $<4.00$ \\
CYP2C9 & $<2.22$ & $<4.32$ \\
CYP2C19 & 11.2 & $<10.0$ \\
CYP2D6 & 3.18 & $<3.64$ \\
CYP2E1 & 0.633 & $<1.07$ \\
CYP3A4 & 18.8 & $<24.6$ \\
\hline
\end{tabular}

* Human AHH-1 TK $+/$ - cell microsomes expressing human cytochrome P 450.

Enzyme incubation and metabolite analysis were carried out in duplicate.

Inequality indicates below the detection limit.

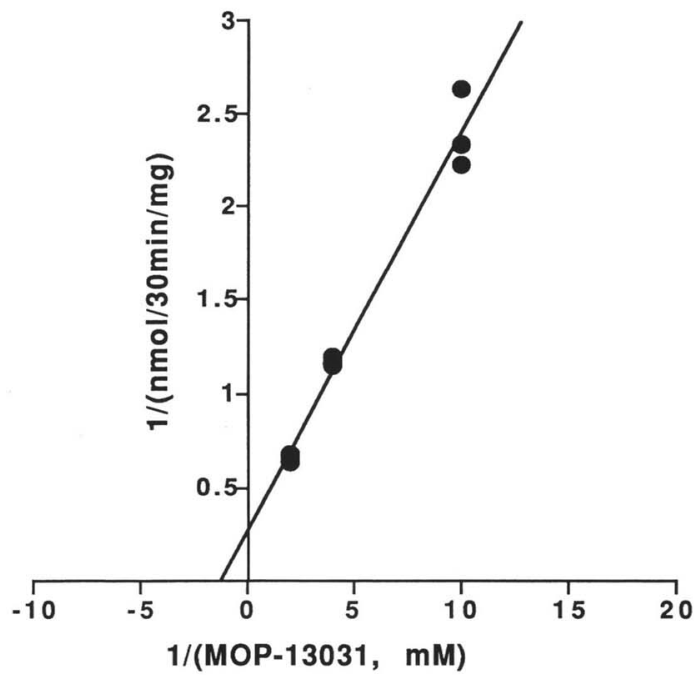

Fig. 3 Lineweaver-Burk plot of the initial velocity of MOP13031 dehydrogenation by microsome-expressed CYP3A4.

Enzyme incubation and metabolite analysis were carried out three times. The linear regression line was $y=0.214 x+0.269(y=0.990)$, yielding estimates 796 $\mu \mathrm{M}$ for the $\mathrm{Km}$ value and $0.124 \mathrm{nmol} / \mathrm{min} / \mathrm{mg}$ protein for the $\mathrm{V}_{\max }$ value.

that CYP3A4 is the principal isoform involved in the catalytic reaction. DM-1312 was not produced by any of the CYP isoforms. Kinetic plots for MOP-13031 dehydrogenase activity catalyzed by CYP3A4 verus the concentration of MOP-13031 are shown in Fig. 3. The apparent $\mathrm{Km}$ and $\mathrm{V}_{\max }$ values were $796 \mu \mathrm{M}$ and 0.124 $\mathrm{nmol} / \mathrm{min} / \mathrm{mg}$ protein, respectively.

Production of DM-1312 from OPC-13463 was not observed by any of the CYP isoforms.
Table III Effects of pranidipine, MOP-13031 and ( \pm )miconazole on CYP3A4-catalyzed testosterone $6 \beta$-hydroxylase activity

\begin{tabular}{lcccc}
\hline \multirow{2}{*}{ Compound } & \multicolumn{4}{c}{ Percentage of inhibition or (stimulation) } \\
\cline { 2 - 5 } & $\begin{array}{c}1 \times 10^{-7} \\
\mathrm{M}\end{array}$ & $\begin{array}{c}1 \times 10^{-6} \\
\mathrm{M}\end{array}$ & $\begin{array}{c}1 \times 10^{-5} \\
\mathrm{M}\end{array}$ & $\begin{array}{c}1 \times 10^{-4} \\
\mathrm{M}\end{array}$ \\
\hline Pranidipine & $\mathrm{NP}$ & 10.4 & 67.4 & 94.7 \\
MOP-13031 & $\mathrm{NP}^{\mathrm{a})}$ & $(9.5)$ & 1.9 & 17.2 \\
$( \pm)$-miconazole & 33.9 & 89.1 & 97.8 & $\left.\mathrm{NP}^{\mathrm{a}}\right)$ \\
\hline
\end{tabular}

a) Not performed. Enzyme incubation and metabolite analysis were carried out in triplicate and the data expressed as mean value.

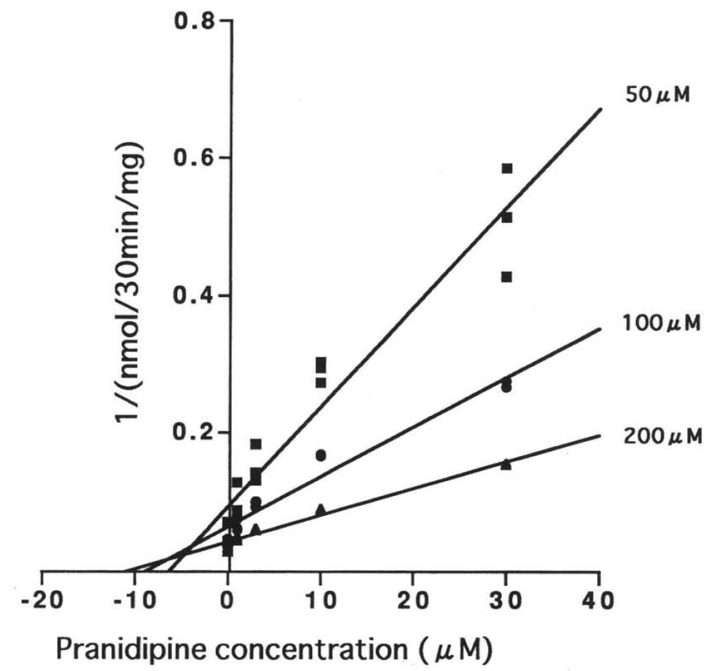

Fig. 4 Dixon plot for the inhibition by pranidipine of terstosterone $6 \beta$-hydroxylase activity catalyzed by microsome-expressed CYP3A4.

Enzyme incubation and metabolite analysis were carried out three times. The linear regression lines were $y=0.014 x+0.093(y=0.962)$ for $50 \mu \mathrm{M}$ testosterone, $y=0.007 x+0.065(\gamma=0.972)$ for $100 \mu \mathrm{M}$ testosterone, and $y=0.004 x+0.043(\gamma=0.986)$ for $200 \mu \mathrm{M}$ testosterone, yielding an estimate of $5.44 \mu \mathrm{M}$ for the $\mathrm{Ki}$ value.

\section{Effects of Chemicals on Testosterone $6 \beta$ - hydroxylation}

Effects of pranidipine, MOP- 13031 and $( \pm)$-miconazole on CYP3A4-catalyzed testosterone $6 \beta$-hydroxylation are shown in Table III. Pranidipine at concentrations of $1 \times 10^{-4}, 1 \times 10^{-5}$ and $1 \times 10^{-4} \mathrm{M}$ inhibited $94.7 \%, 67.4 \%$ and $10.4 \%$, respectively, of the $6 \beta$ hydroxytestosterone formation compared with the control value. No inhibition of CYP3A4-catalyzed testosterone $6 \beta$-hydroxylation by MOP- 13031 at $1 \times 10^{-5} \mathrm{M}$ was observed. $( \pm)$-miconazole at a concentration of $1 \times$ $10^{-5} \mathrm{M}$ completely inhibited the activity.

For pranidipine, the inhibitory kinetics were investigated using microsome-expressed CYP3A4 to determine the apparent Ki value. A Dixon plot illustrating the 
inhibition of testosterone $6 \beta$-hydroxylation by the compound is shown in Fig. 4. Pranidipine competitively inhibited the reaction with a $\mathrm{Ki}$ value of $5.44 \mu \mathrm{M}$.

\section{Effect of Grapefruit Juice Extract on CYP3A4-catalyzed Pranidipine Dehydrogena- tion}

Effect of a grapefruit juice-extract on CYP3A4-catalyzed pranidipine dehydrogenation is shown in Fig.5. Pranidipine dehydrogenase activity was dose-dependently decreased by the addition of grapefruit juice-extracts. A $50 \%$ inhibitory effect of the extracts on the activity was approximately 0.02 in volume equivalence of the original grapefruit juice. Two different brands and three commercially available grapefruit juice were examined in this study. The results showed that all three products inhibited CYP3A4-catalyzed pranidipine dehydrogenation and no difference was observed among three products on the inhibitory effect.

\section{Discussion}

To identify the CYP isoform ( $\mathrm{s}$ ) in the biotransformation of pranidipine, ten isoforms of cDNA-expressed human cytochrome P450 were examined. The results of this study indicated that the formation of dehydrogenated pranidipine is catalyzed only by CYP3A4, and that no other metabolites of pranidipine are produced by any of the CYP isoforms. MOP-13031, which has been identified as a metabolite of pranidipine ${ }^{13)}$ and is possessing a 1,4-dihydropyridine ring in the molecule, was dehydrogenated to a pyridine ring by the multi-isoforms of

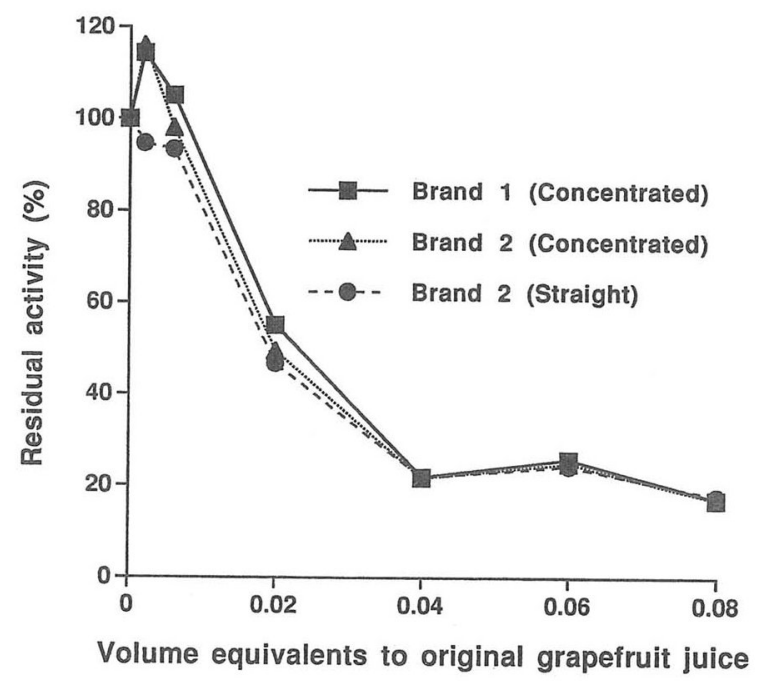

Fig. 5 Effects of grapefruit juice-extracts on CYP3A4-catalyzed pranidipine dehydrogenase activity.

Amounts corresponding to $0.002-0.08$ equivalent volume of the original grapefruit juice were added to $500 \mu l$ of the reaction mixture (1-40 $\mu l$ eq. juice/incubation). Incubations were carried out twice and the data expressed as the mean. cytochrome P450 including CYP3A4, 2C19, 2D6 and $2 \mathrm{E} 1$.

Nifedipine, a 1,4-dihydropyridine calcium antagonist that is widely used in clinical therapy, is the first substrate for CYP3A4 shown by Guengerich et al., ${ }^{16)}$ and it is now commonly agreed that the oxidation of 1,4-dihydropyridine into pyridine is catalyzed by the enzyme. ${ }^{17-20)}$ Pranidipine was also oxidized by the single isoform of CYP3A4 in this study as well as other 1,4-dihydropyridines. Cytochrome $\mathrm{P} 450$ has been demonstrated to catalyze not only the dehydrogenation of 1,4-dihydropyridine ring but also the oxidative cleavage of carboxylic acid esters of Hantzsch pyridine esters to the corresponding carboxylic acid, ${ }^{21-23)}$ presumably following ring oxidation in vivo. ${ }^{24)} \mathrm{A} 2 \mathrm{hr}$ incubation of pranidipine with CYP3A4 produced a dehydrogenated pranidipine metabolite but not methyl 2,6-dimethyl-4-(3nitrophenyl) - 3 -carboxy-5-pyridinecarboxylate, OPC13463. No information is available which CYP isoform $(\mathrm{s})$ is involved in the oxidative cleavage of carboxylic acid ester in 1,4-dihydropyridine calcium antagonists. In pranidipine, CYP3A4 is probably not involved in the oxidative cleavage of the ester linkage but a further investigation is needed to clarify the responsible CYP isoform in the reaction.

MOP-13031 was dehydrogenated by not only CYP3A4 but also by other CYP isoforms. As mentioned above, only CYP3A4 has generally been responsible for the dehydrogenation of 1,4-dihydropyridine. There are few reports on the involvement of CYP isoform(s) except for CYP3A4 in the reaction. We thus believe this is the first study reporting on the involvement of CYP isoforms except for CYP3A4 in the catalytic activity on the dehydrogenation of 1,4-dihydropyridine. The carboxylic esters at the $3-$ or 5-position and substituents at the 4-position of 1,4-dihydropyridine ring did not appear to be important in causing dehydrogenation activity by CYP3A4.19,20) MOP-13031 may thus be dehydrogenated by the multi-CYP isoforms since the compound has a carboxyl group at the 3-position of the dihydropyridine ring and the chemical structure is different compared to the specific dihydropyridine substrate for CYP3A4. However, the catalytic activity by CYP3A4 on the MOP-13031 dehydrogenation was higher than that by the other isoforms, indicating CYP3A4 to be a predominant isoform in the reaction.

The Km for pranidipine or MOP-13031 dehydrogenation by CYP3A4 was $21.4 \mu \mathrm{M}$ or $796 \mu \mathrm{M}$, respectively, and those for the metabolism of various 1,4-dihydropyridines by human liver preparation have been reported as follows: nifedipine $(14.0 \mu \mathrm{M}),{ }^{16)}( \pm)$-felodipine $(6.9$ $\mu \mathrm{M}),{ }^{25)}(\mathrm{R})$ - or (S)-felodipine $(6.1 \mu \mathrm{M}$ or $12.2 \mu \mathrm{M}$, respectively), ${ }^{26)}$ (R) - or (S)-nilvadipine $(14.5 \mu \mathrm{M}$ or $31.0 \mu \mathrm{M}$, respectively), ${ }^{27)}( \pm)-\mathrm{K} 8644(32 \mu \mathrm{M}),{ }^{17)}$ and (+)- or (-)-K8644 (17 $\mu \mathrm{M}$ or $45 \mu \mathrm{M}$, respectively). ${ }^{17)}$ From the above evidence, it seems that the affinity of pranidipine for CYP3A4 is generally similar to those of 
the other 1,4-dihydropyridines whereas that of MOP13031 is the lowest among these conpounds for the enzyme.

Pranidipine and $( \pm)$-miconazole inhibited the CYP3A4-catalyzed testosterone $6 \beta$-hydroxylation with the $\mathrm{Km}$ and $\mathrm{V}_{\max }$ values of $76.9 \mu \mathrm{M}$ and $1.28 \mathrm{nmol} / \mathrm{min} /$ $\mathrm{mg}$ protein, respectively, estimated in our laboratory. MOP-13031 did not inhibited the catalytic reaction. It was considered that the $\mathrm{Km}$ value for pranidipine dehydrogenation was lower than that for testosterone $6 \beta-$ hydroxylation, and so pranidipine competitively inhibited the hydroxylase activity with a relatively low $\mathrm{Ki}$ value of $5.44 \mu \mathrm{M}$. To the contrary, the $\mathrm{Km}$ for MOP-13031 dehydrogenation was higher than that for the hydroxylation, and so MOP-13031 probably did not inhibit the activity. ( \pm )-miconazole is well known as a potent inhibitor for CYP3A4,28) and the inhibitory effect of the compound could be confirmed in this study.

OPC-13463, which is a pyridine metabolite contained a carboxyl group at the 3 -position of the pyridine ring, is one of the main metabolites of pranidipine in humans and the plasma concentration of the metabolite is approximately 5-times higher than that of the unchanged pranidipine. ${ }^{13)}$ It is considered that there are two possible metabolic pathways for the production of OPC13463 from pranidipine: one is via MOP-13031, and the other is via the dehydrogenated pranidipine (Fig. 1). In this study, it was clarified that CYP3A4 plays an important role in the biotransformation of both pranidipine to dehydrogenated pranidipine and MOP-13031 to OPC -13463 . However, it seems that the metabolic clearance of MOP-13031 to OPC-13463 by the enzyme is extremely lower than that of pranidipine to dehydrogenated pranidipine because the intrinsic clearance of MOP13031 metabolism calculated based on the $V_{\max } / \mathrm{Km}$ was lower than that of the pranidipine metabolism, accounting for $0.16 \mu \mathrm{l} / \mathrm{min} / \mathrm{mg}$ protein and $5.14 \mu \mathrm{l} / \mathrm{min} / \mathrm{mg}$ protein, respectively. Accordingly, it was considered that OPC -13463 is presumably produced via the metabolic route of dehydrogenated pranidipine, OPC- 13448 .

A food/drug interaction with grapefruit has been reported for 1,4-dihydropyridine calcium antagonists and an increase in the systemic bioavailability has been shown when these drugs are coadministered with grapefruit juice compared to being administered with water. ${ }^{29)}$ The mechanism of the interaction is considered that grapefruit juice inhibits the first-pass metabolism of a drug metabolized by CYP3A (4) located in the wall of the gut rather than in the liver. ${ }^{30}$ ) Grapefruit juice contains flavonoids such as naringenin, quercetin and kaempferol being as glycosides. It has been considered that these flavonoids are potent active ingredients causing the interaction between grapefruit juice and drugs because the flavonoids, in particular correspond to the aglycones and inhibited the CYP3A activity in vitro. ${ }^{31-34)}$ Nevertheless, the in vivo mechanism ( $\mathrm{s}$ ) causing the drug interaction by grapefruit juice is still un- clear because naringin or quercetin did not cause the in vivo drug interaction, ${ }^{35-37)}$ and neither naringin nor naringenin were primarily responsible for the inhibitory effect in CYP3A activity in vitro. ${ }^{38)}$ Recently, specific CYP3A4 inhibitors have been newly isolated from an ethyl acetate-extract of grapefruit juice and the chemical structures identified were furocoumarin derivatives. ${ }^{15,39)}$ These ingredients strongly inhibited CYP3A4-mediated testosterone $6 \beta$-hydroxylase activity as well as ketoconazole, suggesting new candidates for causative ingredients in grapefruit juice causing drug interaction. ${ }^{39)}$ From the above, we attempted to investigate the effect of an ethyl acetate-extract of grapefruit juice on CYP3A4-catalyzed pranidipine dehydrogenase activity. Our results showed that the pranidipine dehydrogenation by the enzyme was dose-dependently inhibited by the addition of the extract and no differences regarding the inhibitory effect were observed among three products from two different brands of grapefruit juice. These observations were similar to those by Fukuda et al.. ${ }^{15)}$ It was thus considered that the pranidipine dehydrogenation by CYP3A4 was probably inhibited by the furocoumarin derivatives contained in an ethyl acetate-extract of grapefruit juice. To verify the details of the interaction between pranidipine and grapefruit juice, clinical investigation concerning the pharmacokinetics of pranidipine is now in progress.

In conclusion, the combined results obtained from the investigation in the present study of various CYP isoforms clearly demonstrated that the metabolic conversion of pranidipine to dehydrogenated pranidipine was caused mainly by a single isoform CYP3A4. Moreover, it was indicated that the pranidipine dehydrogenation by CYP3A4 was inhibited by an ethyl acetate-extract of grapefruit juice.

\section{References}

1) Nakayama, N., Ikezono, K., Mori, T., Yamashita, S., Nakayama, S., Tanaka, Y., Hosokawa, T., Minami, Y., Masutani, K., Yamamura, Y. and Yabuuchi, Y.: Antihypertensive activity of OPC-13340, a new potent and long-acting dihydropyridine calcium antagonist, in rats. J. Cardiovasc. Pharmacol., 15 (5): 836-844 (1990).

2) Nakayama, N., Ikezono, K., Fujio, N., Sasabe, H., Kitaura, K., Tamada, S., Shirafuji, T. and Yabuuchi, Y.: OPC13340, a new potent and long-acting dihydropyridine calcium antagonist. Cardiovasc. Drug Rev., 9(2): 147-157 (1991).

3) Nakayama., N., Miyakoda, G., Otsuka, M. and Yabuuchi, Y.: Hypotensive effect and cerebral blood flow increasing action of OPC-13340, a new long acting Ca antagonist, in aged SHR. Jpn. Heart J., 32 (4): 561 (1991).

4) Mori, T., Nakayama, N., Ohura, M., Ikezono, K., Kinoshita, S., Kamata, M., Hosokawa, T., Yamashita, S. and Yabuuchi, Y.: Cardiovascular effects of OPC-13340, a potent, long-acting 1,4-dihydropyridine calcium channel blocker, in dogs. Arch. Int. Pharmacodyn., 321: 41-56 (1993). 
5) Broadhurst, P., Brigden, G., Hittel, N., Lahiri, A. and Raftery, E. B.: Prolonged hypotensive effect of OPC13340: A new, once-daily calcium channel blocking drug. Eur. Heart J., 12: 434-438 (1991).

6) Yoshinaga, K., Abe, K., Naitoh, K. and Yamamoto, K.: Clinical evaluation of pranidipine (OPC-13340) in patients with essental hypertension: Double-blind, comparative study with nifedipine retard tablets $\left(\right.$ Adalat $\left.^{\circledR} \mathrm{L}\right)$. J. Clin. Exp. Med., 170 (13): 1097-1121 (1994).

7) Yoshinaga, K., Ishii, M., Iimura, O., Abe, K., Matsuoka, H., Yazaki, Y., Saruta, T., Takeda, R., Ogihara, T., Fujishima, M. and Fukiyama, K.: Clinical usefulness of pranidipine in severe hypertension. Yakuri to Rinsho., 4(5): 1061-1076 (1994).

8) Kato, K., Osada, H., Sugimoto, K., Inoue, H., Hosoda, S., Kishida, H., Iinuma, H., Yamazaki, N., Kawai, C., Fujiwara, H., Hiramori, K., Toyama, S. and Nakashima, M.: A study on optimum dosage of pranidipine in angina pectoris: Multicenter double-blind study. Yakuri to Rinsho., 4(5): 1253-1270 (1994).

9) Kato, K., Osada, H., Sugimoto, K., Inoue, H., Hosoda, S., Kishida, H., Iinuma, H., Yamazaki, N., Kawai, C., Fujiwara, H., Hiramori, K., Toyama, S. and Nakashima, M.:Clinical efficacy and safety of long-term treatment with pranidipine (OPC-13340) in angina pectoris. Yakuri to Rinsho., 4(5): 1287-1299 (1994).

10) Sasabe, H., Futaki, N., Miyamoto, G., Fujio, N., Odomi, M. and Tajima, T.: Metabolic fate of pranidipine (I) . Pharmacokinetics of pranidipine, a new dihydropyridine calcium antagonist, in rats and dogs. Iyakuhin Kenkyu, 24(10): 1070-1078 (1993).

11) Sasabe, H., Futaki, N., Fujio, N., Miyamoto, G. and Odomi, M.: Metabolic fate of pranidipine (II). Absorption and excretion of pranidipine, a new dihydropyridine calcium antagonist, in rats and dogs. Iyakuhin Kenkyu, 24(10): 1079-1086 (1993).

12) Sasabe, H., Futaki, N., Fujio, N., Miyamoto, G., Odomi, M., Esumi, Y. and Okazaki, T.: Metabolic fate of pranidipine (III). Distribution of pranidipine, a new dihydropyridine calcium antagonist, in rats. Iyakuhin Kenkyu, 24(10): 1087-1100 (1993).

13) Sasabe, H., Futaki, N., Matsuki, K., Morita, S., Uchida, M., Miyamoto, G. and Odomi, M.: Metabolic fate of pranidipine (IV). Metabolism of pranidipine, a new dihydopyridine calcium antagonist, and identification of metabolites in rats, dogs and human. Iyakuhin Kenkyu, 24(10): 1101-1114 (1993).

14) Fujita, T., Takagi, N., Takeshige, K., Ogawa, K., Toki, T., Futaki, N., Sasabe, H., Odomi, M. and Ohnishi, A.: Pharmacokinetics of pranidipine in healthy volunteers ( $1^{\text {st }}$ report): Results of single and repeated administration. Yakuri to Rinsho., 4(5): 889-901 (1994).

15) Fukuda, K., Ohta, T. and Yamazoe, Y.: Grapefruit component interacting with rat and human P450 CYP3A: Possible involvement of non-flavonoid components in drug interaction. Biol. Pharm. Bull., 20(5): 560-564 (1997).

16) Guengerich, F. P., Martin, M. V., Beaune, P. H., Kremers, P., Wolff, T. and Waxman, D. J.:Characterization of rat and human liver microsomal cytochrome P450 forms involved in nifedipine oxidation, a prototype for genetic polymorphism in oxidative drug metabolism. J. Biol. Chem., 261(11): 5051-5060 (1986).
17) Guengerich, F. P. and Böcker, R. H.: Cytochrome P-450catalyzed dehydrogenation of 1,4-dihydropyridine. J. Biol. Chem., 263 (17): 8168-8175 (1988).

18) Gonzalez, F. J., Schmid, B. J., Umeno, M., McBride, O. W., Hardwich, J. P., Meyer, U. A., Gelboin, H. V. and Idle, J. R.: Human P450 PCN1: Sequence, chromosome localization, and direct evidence through cDNA expression that $\mathrm{P} 450 \mathrm{PCN} 1$ is nifedipine oxidase. DNA, $7(2)$ : 79-86 (1988).

19) Geungerich, F. P., Brian, W. R., Iwasaki, M., Sari, M-A., Bäärnhielm, C. and Berntsson, P.: Oxidation of dihydropyridine calcium channel blockers and analogues by human liver cytochrome P-450 III A4. J. Med. Chem., 34: 1838-1844 (1991).

20) Guengerich, F. P.: Cytochrome P450 of human liver. Classification and activity profiles of the major enzymes. in Pacifici, G. M. and Fracchia, G. N., (eds.): Advances in Drug Metabolism in Man., pp 181-231, Luxembourg, Belgium; ECSC-EC-EAEC, (1995).

21) Guengerich, F. P.: Oxidative cleavage of carboxylic esters by cytochrome P450. J. Biol. Chem., 262 (18): 8459-8462 (1987).

22) Guengerich, F. P., Peterson, L. A. and Böcker, R. H.: Cytochrome $\mathrm{P}-450$-catalyzed hydroxylation and carboxylic acid ester cleavage of Hantzsch pyridine esters. J. Biol. Chem., 263 (17): 8176-8183 (1988).

23) Funaki, T., Soons, P. A., Guengerich, F. P. and Breimer, D. D.: In vivo oxidative cleavage of a pyridine-carboxylic acid ester metabolite of nifedipine. Biochem. Pharmacol., 38 (23) : 4213-4216 (1989).

24) Raemsch, K. D. and Sommer, J.: Pharmacokinetics and metabolism of nifedipine. Hypertension (Suppl. II), 5: II18-II-24 (1983).

25) Bäärnhielm, C., Dahlbäck, H. and Skånberg, I.: In vivo pharmacokinetics of felodipine predicted from in vitro studies in rat, dog and man. Acta Pharmacol. Toxicol., 59: 113-122 (1986).

26) Eriksson, U. G., Lundahl, J., Bäärnhielm, C., and Regårdh, C. G.: Stereoselective metabolism of felodipine in liver microsomes from rat, dog, and human. Drug Metab. Dispos., 19(5): 889-894 (1991).

27) Tokuma, Y. and Noguchi, H.: Stereoselective pharmacokinetics of dihydopyridine calcium antagonists. J. Chromatogr. A, 694: 181-193 (1995).

28) Parkinson, A.: Biotransformation of xenobiotics. in Klaassen, C. D. (ed.): Casarett and Doull's Toxicology, The Basic Science of Poisons, Fifth Edit., pp 152-153, NY; McGrawHill, 1996.

29) Bailey, D. G., Arnold, J. M. O. and Spence, J. D.: Grapefruit juice and drugs. How significant is the interaction? Clin. Pharmacokinet., 26(2): 91-98 (1994).

30) Ducharme, M. P., Warbasse, L. H. and Edwards, D. J.: Disposition of intravenous and oral cyclosporine after administration with grapefruit juice. Clin. Pharmacol. Ther., 57: 485-491 (1995).

31) Buening, M. K., Chang, R. L., Huang, M-T., Fortner, J. G., Wood, A. W. and Conney, A. H.: Activation and inhibition of benzo (a) pyrene and aflatoxin $\mathrm{B}_{1}$ metabolism in human liver microsomes by naturally occurring flavonoids. Cancer Res., 41: 67-72 (1981).

32) Guengerich, F. P. and Kim, D-H.: In vitro inhibition of dihydropyridine oxidation and aflatoxin $\mathrm{B}_{1}$ activation in hu- 
man liver microsomes by naringenin and other flavonoids. Carcinogenesis, 11(12): 2275-2279 (1990).

33) Miniscalco, A., Lundahl, J., Regårdh, C. G., Edgar, B. and Eriksson, U. G.: Inhibition of dihydropyridine metabolism in rat and human liver microsomes by flavonoids found in grapefruit juice. J. Pharmacol. Exp. Ther., 261(3): 11951199 (1992).

34) Ha, H. R., Chen, J., Leuenberger, P. M., Freiburghaus, A. U. and Follath, F.: In vitro inhibition of midazolam and quinidine metabolism by flavonoids. Eur. J. Clin. Pharmacol., 48: 367-371 (1995).

35) Rashid, J., McKinstry, C., Renwick, G., Dirnhuber, M., Waller, D. G. and George, C. F.: Quercetin, an in vitro inhibitor of CYP3A, does not contribute to the interaction between nifedipine and grapefruit juice. Br. J. Clin. Pharmacol., 36: 460-463 (1993).
36) Bailey, D. G., Arnold, J. M. O., Munoz, C. and Spence, J. D.: Grapefruit juice-felodipine interaction: Mechanism, predictability, and effect of naringin. Clin. Pharmacol. Ther., 53: 637-642 (1993)

37) Bailey, D. G., Arnold, J. M. O., Strong, H. A., Munoz, C. and Spence, J. D.: Effect of grapefruit juice and naringin on nisoldipine pharmacokinetics. Clin. Pharmacol. Ther., 54: 589-594 (1993).

38) Edwards, D. J. and Bernier, S. M.: Naringin and naringenin are not the primary CYP3A inhibitors in grapefruit juice. Life Sci., 59(13): 1025-1030 (1996).

39) Fukuda, K., Ohta, T., Oshima, Y., Ohashi, N., Yoshikawa, M. and Yamazoe, Y.: Specific CYP3A inhibitors in grapefruit juice: Furocoumarin dimers as components of drug interaction. Pharmacogenetics, 7: 391-396 (1997). 